\title{
Hudba jako inspirace Komenského konceptu harmonické společnosti
}

\author{
Vladimír PŘÍVRATSKÝa a Jana PříVRATSKÁ ${ }^{\mathrm{b}}$ \\ ${ }^{a}$ Univerzita Karlova, Pedagogická fakulta, katedra psychologie, Praha, Česká republika \\ b Univerzita Karlova, 3. lékařská fakulta, Ústav jazyků, Praha, Česká republika
}

Je naprosto přirozené a nikoho nepřekvapuje, když velkým osobnostem národa, a zejména těm, jejichž myšlenkový odkaz se stal součástí světové kultury, věnují umělci svou pozornost, zpodobují je nebo se jimi nechají ve své umělecké tvorbě inspirovat. Je proto logické, že postupně vznikají i badatelské příspěvky, jež se zaměřují právě na uměleckou tvorbu inspirovanou myšlenkovým odkazem Jana Amose Komenského. To platí v plné míře i pro oblast hudebního umění. I když není cílem tohoto př́íspěvku zaměřovat se na hudební tvưrce, jež oslovil Komenského pohnutý život a rozsáhlé dílo, je vhodné v návaznosti na téma konference Odkaz Komenského v umění a uměleckém vzdělávání (Praha, květen 2019) alespoň připomenout, že hudební díla jím inspirovaná představují velké spektrum hudebních žánrů a forem - od jednoduchých písní až po náročná vokální díla pro početná pěvecká tělesa, od skladeb pro malé nástrojové obsazení až po rozměrná díla symfonická. $\mathrm{Z}$ námětů se uplatňují především Komenského Labyrint světa a Obecná porada o nápravě věci lidských, ale i jiné Komenského texty. Mezi touto bezmála stovkou hudebních děl vznikajících zejména v 19. a 20. století a věnovaných Komenskému jsou kompozice vytvořené skladateli věhlasného jména jako např. Zdeněk Fibich, Josef Bohuslav Foerster, Leoš Janáček, Petr Eben, oba bratři Jeremiášové, Emil Hába, Miroslav Kabeláč, Iša Krejčí, Jaroslav Křrička, Jaroslav Krček, Otmar Mácha či Miloš Štědroň a mnozí další. Mimochodem je třeba v této souvislosti poznamenat, že v odborné literatuře dosud chybí ucelená, komplexní monografie, která by tuto problematiku systematicky zpracovala. To, co bylo řečeno, je ovšem jen jednou stránkou obapolného vztahu Komenský a hudba. Tento př́íspěvek však právě proto, že představuje určitý vstup do hudební tematiky spojené s tímto českým myslitelem, se pokusí o pravý opak, totiž soustředí se na komeniologickou otázku, zda a př́padně jak ovlivnila hudba Komenského myšlení.

Hudba představovala $\mathrm{v}$ Jednotě bratrské důležitou složku duchovního života jejích členů (Settari, 1984, s. 32-40). Uplatňovali ji nejen při bohoslužbách, ale vnímali ji i jako přirozenou součást výchovy a v obecném slova smyslu jako způsob svého života (Settari, 1991, s. 156-159). Vzhledem ke Komenského zakotvenosti v tradicích Jednoty bratrské lze předpokládat, že již od útlého dětství byl zdatným zpěvákem bratrských duchovních písní. Později jako jinoch za studií v zahraničí (v Německu) velmi dobře poznal dobovou hudební teorii a středověké traktáty o hudbě. Není známo, zda sám ovládal hru na nějaký nástroj, avšak z texto̊ jeho děl, které se týkají hudby a hudební výchovy, lze předpokládat, že přece jen 
získal hlubší hudební vzdělání, než bylo tehdy u studentů teologie běžné, a že si sám průběhem dalších let tyto základy doplňoval. Univerzitní studia mu dala jistě spolehlivý základ už jen proto, že hudba náležela tehdy k sedmi tzv. svobodným uměním, a to do skupiny quadrivia (spolu s aritmetikou, geometrií a astronomií), jež byla povinnou součástí studia na univerzitách ${ }^{1}$. K běžné praxi patřilo tehdy zvládnutí zpěvu duchovních písní, na které později Komenský ve své koncepci hudební výchovy (Tamtéž, s. 157-158), zejména pak ve škole pansofické, klade takový důraz. Přirozený vliv prostředí, respektování zásad Jednoty bratrské v otázkách hudební výchovy i ovlivnění tradicí ve vyučování hudbě a zpěvu znamenaly, že Komenský preferoval vokální hudbu, i když ani nástrojovou hudbu ze své koncepce zcela nevyloučil a s přibývajícím věkem ji hodnotil příznivě.

Avšak klíčovým důvodem Komenského vztahu k hudbě je jeho přesvědčení, že hudba je postavena na harmonii, cvičí hudební představivost a vnímavost a zejména určuje praktická pravidla, jak harmonie dosahovat. Je tedy jakýmsi modelem, který může dobře posloužit při hledání a dosahování harmonických vztahů, a současně inspirací k úsilí nalézat a vytvářet takové vztahy mezi lidmi, jež umožní založit společnost trvale harmonickou. Takovou, která do sebe vstřebá princip vyjádřený již Mikulášem Kusánským pojmem coincidentia oppositorum $^{2}$, tedy soulad, splývání protikladů. Jan Patočka považoval myšlenku harmonie vyvíjející se v panharmonii u Komenského za naprosto fundamentální, představil ho jako prvního myslitele, který pochopil, že starobylá idea všeobecné harmonie ukáže teprve svou racionalizační sílu ve výuce a výchově (Patočka, 1998, s. 141-142). Proto také hudba jako nástroj k nastolení všeobecné harmonie je Komenskému součástí jeho edukační koncepce a zabývá se jí i ve spisech zaměřených filosoficky.

Názory a požadavky na hudební průpravu a výchovu shledáváme $\mathrm{v}$ mnoha textech Komenského věnovaných vzdělávání a škole. Tak například v Informatoriu školy mateřské se dozvídáme, že děti se učí zpaměti zpívat veršíky od narození a hudbě mají naslouchat již od druhého roku života (Komenský, 1958, s. 298, 307). Hudba je nám podle Komenského nejpřirozenější a libá je dětem od nejútlejšího věku, zejména „zpívání, hudení, helekání, břinkání, zvonění, hrání na nástroje múzické. Protož jim toho mírně dodávati, aby k melodii a harmonii uši i mysl jejich zvykaly“ (Tamtéž, s. 315). Ve Škole vševědné (Schola pansophica) Komenský požaduje, aby se žáci cvičili v hudbě tím, že budou zpívat (zejména svaté písně) ve škole, v kostele, tak i v soukromí, a to všichni, urození i neurození. Také figurální, tj. vícehlasá hudba má mít své hodiny, ,aby i studium harmonie vzkvétalo plně v harmonické škole“ (Týž, 1960, s. 51). Žádá rovněž zavedení hudebních nástrojů, zejména u dětí z movitějších šlechtických rodin (Tamtéž, s. 50-51). Komenský začlenil hudbu k matematice s tím, že svět a všechno harmonické, je zřízeno a zřizuje se podle čísel, měr a vah a to platí i o hudbě. Proto se mají žáci na tomto stupni vzdělávání cvičit ve stupnicích

\footnotetext{
${ }^{1}$ Též heslo Hudba a Komenský (autorka O. Settari), Encyclopaedia Comeniana (připraveno pro publikaci).

2 Kusánův pojem ,coincidentia oppositorum', podle nějž vládnou v našem světě protiklady, které ale v nekonečnu splývají. Tento pojem M. Kusánský uplatňuje zejména ve svém spise De docta ignorantia (O učené nevědomosti) z r. 1440.
} 
a znalosti klíčů (Tamtéž, s. 58). Ve vyšších ročnících školy vševědné pak žádá symfonii, tj. vícehlasý zpěv nebo hudbu (Tamtéž, s. 61). Vše je pak završeno v tzv. tř́dě filosofické, kam Komenský přidává hudbu instrumentální (Tamtéž, s. 63).

I když Komenský nenapsal žádný spis, který by se př́imo a cele hudbě věnoval, nalézáme názory na hudbu v řadě jeho prací, jako jsou Didactica magna, Janua lingvarum reserata, Orbis pictus, Schola ludus, Pansophiae praeludium, Moudrost starých Čechů, O poesi české aj. V Předehře pansofie (Pansophiae praeludium), kde Komenský vychází z původního pojetí pojmu harmonie, píše na s. 82 , že harmonií nazývají hudebníci př́ijemný souzvuk mnoha hlasů, a spatřuje tentýž souzvuk 1) věčných vlastností v Bohu, 2) stvořených vlastností v př́rodě a 3) vlastností vyjádřených v umění. Podobně je tomu i v Obecné poradě, kde koncept hudební harmonie je inspirativní pro myšlenku panharmonie, jež tvoří základ sice složité, ale přesto dobře uspořádané lidské společnosti, kterou lze společným úsilím vytvořit. V druhé části tohoto opus grande, Panaugii, metaforicky charakterizuje panharmonii př́mo takovými hudebními vlastnostmi, jako jsou soulad, souzvuk tónu nebo hlasů: „Harmonií nazývají hudebníci libou souzvučnost více hlasů, at' už by to byly hlasy živé, či vyluzované tlučením nebo troubením na nějaký hudební nástroj. Je pro uši i duše tím libější, čím více se na ní podílí pěveckých sborů nebo nástrojů. Zvláště tehdy je vhodné mluvit o PAN-HARMONII, tj. plné a všeobecné souzvučnosti všeho se vším“ (Panaugia, 1992, s. 174). A dále připojuje: „Protože i my jsme tedy účastni Božích hlasů (zaznívajících zajisté ve výrocích Božích slov, smyslově postižitelných v díle Božích rukou a rozléhajících se šepotem v nejtajnějších koutech naší duše), je třeba se usilovně starat o to, aby se zde neobjevil nějaký nesouzvuk, od jehož nelibozvučnosti by se náš duch odvracel, a tak se zbavoval poslechu té božské hudby. Také je třeba se postarat, aby sám, předpokládaje nesouzvučnost, neupadal do nějaké nelibozvučnosti.“ (Tamtéž, s. 174).

Princip panharmonie spočívá v Komenského celoživotním úsilí nalézt způsob, jak vyvést lidstvo z labyrintů, jež si samo přivodilo, a jak vytvořit společnost novou, kde budou vzájemně harmonicky existovat hlavní věci lidské, totiž filosofie, politika a náboženství, a působit ve prospěch každého člověka takové společnosti. Komenský při tom vychází z lidské přirozenosti. Lidská vznešenost (výjimečnost) má tři kořeny, které jsou vlastní jen lidskému duchu: rozum, vůli a puzení $\mathrm{k}$ činům. Právě $\mathrm{z}$ lidské touhy po pravdě pochází filosofie, $\mathrm{z}$ touhy po dobru vzniká zbožnost a z vůle uspořádat věci podle svého pochází v konečném důsledku politika (Schifferová, 2014, s. 54). Jaký je jejich smysl? Účelem filosofie je smír mysli s věcmi, účelem náboženství smír svědomí s Bohem, účelem politiky duševní smír mezi lidmi. Přičemž politika je podle Komenského vedení lidí, kteří stále něco podnikají, a to podle takových pravidel, aby si v tom, co dělají, navzájem nepřekáželi, nýbrž pomáhali (Tamtéž, s. 54).

Avšak uvažujeme-li o Komenského inspiraci hudbou, je třeba zmínit ještě jeden důležitý aspekt, v němž základní hudební vlastnosti nalézaly uplatnění při Komenského úvahách 
o cestách, jak napravit lidskou společnost, připravit její stabilitu a nastolit navzdory veškeré společenské rozmanitosti trvalý mír. Je to vliv hudební struktury, vliv jejích zákonitostí při úvahách Komenského o tvorbě nového univerzálního jazyka. Inspirací mu byl v tomto ohledu francouzský učenec, matematik a filosof Marin Mersenne (1588-1648), který se kromě těchto oborů věnoval hudební teorii, některým fyzikálně akustickým otázkám a byl rovněž autorem několika hudebních skladeb. Pozoruhodný je Mersennův podíl a vliv na dobovou diskusi o potřebě a hledání dokonalého univerzálního jazyka. Již ve druhé polovině 20. let 17 . století se Mersenne zabýval otázkou takového jazyka, kde slova by byla analogická věcem. Do svého spisu Harmonie universelle (Univerzální harmonie) z r. 1636 vložil svůj návrh na vytvoření takového jazyka. Zvláštním rysem Mersennova pojetí je inspirace hudební harmonií a teorií, zejména vztahem vokálního vyjádření a notového záznamu jako analogie k hledanému univerzálnímu jazyku. Komenský rovněž hledal pro svůj všenápravný projekt takový jazyk, který by uváděl do souladu věci a pojmy, jimiž by věcný svět co nejpřesněji vyjadřoval (Komenský, 1961, s. 122) . $^{3}$ Z korespondence víme (např. dopis z 22. listopadu $1640)^{4}$, že byl Mersenne s Komenským v písemném kontaktu a o své práci se vzájemně informovali, přičemž Mersenne pochopil souvislost úvah o jazyce s Komenského pansofií. Pokus Komenského o nový univerzální jazyk se opíral o představu možného harmonického vztahu mezi věcmi, myšlením (tj. jejich duševním uchopením) a jazykem, který má schopnost tento vztah vyjadřovat, sdělovat a posilovat, a tímto způsobem přispět k rozvoji společnosti na principu harmonie založené. Inspirace hudbou je přitom na počátku vývoje tohoto myšlenkového paradigmatu zřejmá, nebot' harmonie, později pak panharmonie je mu jakýmsi krystalem metafory z oblasti hudby, protože právě v ní je obsažen soulad jako souzvuk tónů. Univerzální jazyk $^{5}$ (viz spis Panglottia) ${ }^{6}$ spolu s univerzálním vzděláváním (Pampaedia) a všenápravou (Panorthosia) jsou tedy procesy představující prostředky, jak dosáhnout trvale udržitelné, harmonické společnosti schopné se rozvíjet s vyloučením válečných konfliktů.

Můžeme tedy shrnout, že hudba jako výlučně lidský fenomén a její zákonitosti odrážející dimenze člověka přesahující (Bůh, vesmír, příroda) se staly bytostnou součástí Komenského pojetí harmonického uspořádání lidské společnosti.

\footnotetext{
${ }^{3}$ Komenský o vlastnostech tohoto jazyka pojednává nejen v Panglottii, ale již dř́ive do spisu Via lucis (Cesta světla) zařadil kapitolu (XIX) nazvanou Linguae universalis ratio (Způsob universálního jazyka).

${ }^{4}$ PATERA, Adolf, 1892. J. A. Komenského Korrespondence. XIX, Epistola M. Mersenni ad J. A. Comenium, s. 192.

${ }_{5}^{5}$ Srov. též PŘíVRATSKÁ, Jana, 2000. Lingua perfecta. Zamyšlení nad kritérii Komenského při hodnocení jazyků. Bulletin Unie Comenius. Roč. 8 , č. 12, mimořádné číslo k životnímu jubileu prof. PhDr. Dagmar Čapkové, DrSc., s. 94-100. ISSN 1213-1776.

${ }^{6}$ PŘÍVRATSKÁ, Jana, 1996. Panglottia - Comenius` Model for Language Unification. In: JANKOWSKY, Kurt R., ed. Multiple Perspectives on the Historical Dimensions of Language. Münster: Nodus Publikationen, s. 7580, ISBN 3-89323-270-2.
} 


\section{Primární zdroje}

KOMENSKÝ, J. A., 1958. Informatorium školy mateřské. Vybrané spisy Jana Amosa Komenského, sv. I. Praha: SPN.

KOMENSKÝ, J. A., 1960. Škola vševědná. Vybrané spisy Jana Amosa Komenského, sv. II. Praha: SPN.

KOMENSKÝ, J. A., 2010. Předehra pansofie. Objasnění pansofických pokusů. Překlad M. Klosová. Praha: Academia. ISBN 978-80-200-1862-5.

KOMENSKÝ, J. A., 1992. Panaugia, kap. X, § 8 (překlad. J. Hejlek). In: Obecná porada o nápravě věcí lidských. Sv. I. Praha: Svoboda.

MERSENNE, Marin, 1963. Harmonie universalle. Faksimile orig. vyd. z r. 1636. Paris.

KOMENSKÝ, J. A., 1992. Panglottia. In: Obecná porada o nápravě věcí lidských. Sv. III. Praha: Svoboda. ISBN 80-205-0226-2.

KOMENSKÝ, J. A., 1961. Cesta světla (Via lucis). Kap. XIX. Praha: SPN.

PATERA, Adolf, 1892. Jana Amosa Komenského Korrespondence. Praha.

\section{Literatura}

SETTARI, Olga, 1984. Českobratrská hudební produkce v díle Jana Blahoslava a Jana Amose Komenského. ZKT XI. Kralice nad Oslavou: Muzejní spolek.

SETTARI, Olga, 1991. Jan Amos Komenský - hudební teoretik, pedagog a hymnograf. In: Pocta Univerzity Karlovy J. A. Komenskému. Praha: Karolinum, s. 155-163.

SETTARI, Olga. Hudba a Komenský. In: Kolektiv autorů. Encyclopaedia Comeniana. (připraveno $\mathrm{k}$ publikaci).

PATOČKA, Jan, 1998. Komenský a hlavní filosofické myšlenky 17. století. In: PATOČKA, Jan a SCHIFFEROVÁ, Věra, ed. Komeniologické studie. Soubor textů o J. A. Komenském. První díl: Texty publikované v letech 1941-1958. Praha: OIKOYMENH, s. 141-142.

SCHIFFEROVÁ, Věra, 2014. Idea harmonie v díle Jana Amose Komenského. In: SCHIFFEROVÁ, Věra, et al. Idea harmonie v díle Jana Amose Komenského. Červený Kostelec: Pavel Mervart. ISBN 978-80-7465-093-2. 